Published as: Martinus, K., lacopini, I., Sigler, T. \& Derudder, B. (2019). The Role of Tax Havens and Offshore Financial Centers in Asia-Pacific Networks: Evidence from Firm-Subsidiary Connections.

Asian Business \& Management, 18(5), 389-411. 
See discussions, stats, and author profiles for this publication at: https://www.researchgate.net/publication/329435404

The role of tax havens and offshore financial centers in Asia-Pacific networks: evidence from firm-subsidiary connections

Article in Asian Business \& Management · December 2018

DOI: 10.1057/541291-018-00051-1

CITATIONS

2

4 authors:

Kirsten Martinus

University of Western Australia

60 PUBLICATIONS 242 CITATIONS

SEE PROFILE

lacopo Iacopini

Queen Mary, University of London

11 PUBLICATIONS 60 CITATIONS

SEE PROFILE

Some of the authors of this publication are also working on these related projects:

Kritische Massa View project

Project Labour proximity in institutionally-thin innovative peripheries View project
303

Thomas Sigler

The University of Queensland

48 PUBLICATIONS 315 CITATIONS

SEE PROFILE

Ben Derudder

Ghent University

224 PUBLICATIONS 3,640 CITATIONS

SEE PROFILE 


\title{
The Role of Tax Havens and Offshore Financial Centers in Asia-Pacific Networks:
}

\section{Evidence from Firm-Subsidiary Connections}

\begin{abstract}
:
This paper adds a network dimension to locational theories on multinational corporate strategy to explain how tax havens and offshore financial centers (THOFC) are integrated into the structures of firms listed on five stock exchanges of the Asia-Pacific region. Applying network analysis to firm-subsidiary connections of these listed firms, it highlights differences in the connectivity structures as well as the role of THOFC in exchange subnetworks. It finds considerable variation in the complexity of corporate structures by stock exchange can be explained by national context and multinational location strategies, and that the prevalence of THOFC within corporate structures cannot be underestimated.
\end{abstract}

Keywords: Tax havens; Offshore Financial Centers; Social Network Analysis; Economic Geography; Financial Markets

\section{Introduction}

The position of tax havens and offshore financial centers (THOFCs) in multinational firm networks is an increasingly germane research topic due to the strong role these jurisdictions play in global capital flows. Their emergence as a component of corporate operations is not new, but their role as key actors shaping global financial flows has risen dramatically. According to Damgaard et al. (2018), THOFCs harbor $\$ 7$ trillion in private wealth and $\$ 12$ trillion in corporate wealth through corporate shells, accounting for $40 \%$ of global foreign direct investment (FDI). Alstadsaeter et al. (2018) estimate that the equivalent of $10 \%$ of global gross domestic product (GDP) is held in tax havens, or $8 \%$ of household financial wealth $(\$ 7.6$ 
trillion in 2007). Though widely perceived to be a 'failure' in governance (Wojcik, 2013) or tied to illicit funds (Aalbers, 2018), the fact that most - if not all - of the world's largest corporations pursue tax minimization strategies in some form through THOFCs renders them worthy of both further research and better theorization.

Within the international business (IB) literature, research on THOFCs has focused primarily on tax and regulatory regimes (Fitchner, 2016; Kemme et al., 2017); firm strategy and advantage (Cobham et al., 2015; Sutherland et al., 2012); and, the nature of foreign direct investment (Andreff, 2016; Palan et al., 2009). However, with the exception of a few key texts (García-Bernardo et al., 2017), there is a dearth of literature on the geographical drivers and networked processes of corporate structures relating to THOFCs. Scholars have noted that the geographical distribution of multi-national corporation (MNC) activity is influenced by a variety of determinants, including producer and consumer markets, regulation, and access to factors of production including labor, resources, and capital (Yang, \& Coe, 2009; Yeung, 2014). Much of this is based on research emerging from the 1960s, which theorizes the MNC as an outgrowth of the global capitalist order focusing initially on the 'foreign' operations of 'domestic' firms and later turning to more comprehensive and complex theorization (cf. Buckley, 1985). Indeed, the ease with which flows of capital now transcend national boundaries in the digital era has rendered the geographical structure of MNCs more and more complex, being driven by individual firm strategy as well as factors specific to industry sectors. As intensifying neoliberalization has broken down territorialized national production systems, MNC are increasingly incorporating THOFCs into their operational networks (Desai, \& Dharmapala, 2006; Roberts, 1995; Schotter et al., 2017).

Against this backdrop, this paper analyzes the role of THOFCs in five firm-subsidiary locational networks derived from the MNCs listed on five Asia-Pacific stock exchanges: the Australian Securities Exchange, Bombay Stock Exchange, Shanghai Stock Exchange, 
Shenzhen Stock Exchange and Tokyo Stock Exchange. The resultant analysis applies network analytics to understand the role THOFC within firm networks. It finds that differences in national context appear to be reflected in how MNCs strategically globalize which, when aggregated, reveal the global nature and arrangements of THOFC flows. The Asia-Pacific comparative approach reveals differences across varieties of capitalism in the countries of this study. We conclude that it is apparent through the different network structures that national context and MNC strategies both impact how firms globalize and the role of THOFCs therein.

\section{The Role of Location and Networks in the International Business (IB) Literature}

The IB literature has provided a core analytical framework for more than half a century, focusing on a number of interrelated dimensions including firm strategy, competitive advantage, regulation, and change over time (e.g. Buckley, 1985; Caves, 1974; Dunning, 2014; Dunning, \& Lundan, 2008; Fan et al., 2016; Markusen, 1995). Within IB, the OwnershipLocation-Internalization (OLI) framework (Dunning, 2001) provides an 'eclectic' theory detailing why and where firms expand internationally. Through its various iterations of theory over the past decades, the 'location' component of OLI has been perhaps most neglected (Dunning, 2014; Buckley, 1985), possibly owing to the fact that analyses of locational factors have been divided between regional scientists, geographers, and business scholars.

In general, theories of MNC activities from a business or economic theoretical perspective seek to explain 'both the location of value-adding activities, and the ownership and organization of these activities' (Dunning, \& Lundan, 2008, p.79). (Neo)classical spatial economics of the 1950s focused on examining the question of 'where', making broad assumptions on the spatial fixity of resources and labor, and the increasingly influential role of the firm in directing crossborder transactions as driven by profit motives. However, as neoliberalism further eroded the relevance of national boundaries in 'containing' firm activity, scholarship in the 1970s and 80s 
began to explore the question of 'how' and 'why' (Dunning, \& Lundan, 2008). This situated MNC activity geographically.

Though location is critical to explaining firm strategy and economic systems, networked perspectives have recently made considerable inroads in providing evidence as to how global economic systems are structured. Research on corporate networks has thus proposed shifting the focus from traditional dyadic relationships (firms investing in other countries on an ad hoc basis) to a larger context of network relationships. Alderson et al. (2010), Wall and van der Knaap (2011) and Taylor et al. (2014), for example, employ techniques developed for the analysis of networks to evaluate how locations are linked together by MNCs in terms of the positions they occupy and roles that they play in those firms' corporate networks.

The notion that firms interact across the globe through various production and consumption networks shaped by different political and institutional structures is by now a well-accepted premise in a variety of academic disciplines, given the decades of research by theorists exploring corporate globalization (Dicken, 2011), neoliberalization (Peck et al., 2018), world city networks (Sigler \& Martinus, 2017; Taylor, \& Derudder, 2018) and global production networks (Coe et al., 2004; Yeung, \& Coe, 2015). Empirical research drawing on these understandings is broad in methodological scope and data, but largely focuses on spatial network patterns of global corporate activities. Collectively, this literature theorizes how the globalization processes associated with power and control have shaped economic relations and production networks. More recent studies have expanded beyond the initial focus on 'global cities' towards alternative geographic areas and industry sectors (e.g., Krätke, 2014; Robinson, 2002; Grant, \& Nijman, 2002). IB has also begun to explore how social network analysis can inform understandings of MNC operations and strategies, such as the influence and role of inter-locking directors (e.g. Guo, \& Lv, 2018) and value creation processes of international networking (e.g. Vedel, \& Servais, 2017). This body of work remains largely outside of the 
geographic or locational context, with studies dealing the identification of locations rather than the connection between them (e.g. McCarthy, \& Dolfsma, 2016). As such, drawing on MNC strategic operational and locational decision-making literature from the respective international business and global cities research fields is highly relevant to progressing understandings of global economic networks and flows.

\section{The Emergence of Asia-Pacific Multinational Firm Activity}

While the number and geographic diversity of MNCs has steadily risen, some argue that the distribution of global corporations - particularly those listed on the world's largest stock exchanges - remains concentrated in the economies of North America, Western Europe and Japan (Forsgren, 2013; Rugman, \& Verbeke, 2004). There has nonetheless been a degree of change to this concentration, with emerging Asian economies becoming fast-rising hubs for global firm headquarters, and by corollary corporate knowledge and innovation. For example, four of the top ten, and nine of the top 20 stock exchanges ranked by market capitalization are now in the Asia-Pacific region, and many of the most significant industry giants are Asian. Unlike many Western firms, one notable feature of Asia-Pacific MNCs is that a relatively high proportion are either state-backed or state-owned, particularly in the case of China (Andreff, 2016). While large Japanese and Korean firms (e.g., Toyota, Samsung, Sony, LG) have long been household names, large Chinese (e.g., Alibaba, Baidu, Tencent, Xiaomi) and Indian (Tata, Infosys) firms have increasingly caught the attention of both commentators and researchers (Williamson, \& Yin, 2014).

The distribution of global MNC activity to some degree mirrors underlying economic processes. Rugman and Verbeke (2004) argue that most MNCs are regional rather than truly global in their locational strategies. For example, many MNCs demonstrate a strong homeregionalization because economic activities within the home market are operationally cheaper, 
more efficient and easier than across several markets. In addition, MNCs appear to follow a set of common rules with differences relating to their own national particulars (Andreff, 2016). For example, Australian MNCs have been found to strongly pursue locational strategies associated with the country's colonial links to the United Kingdom and geographic links to the Asia-Pacific (Kim, \& Gray, 2017; Taylor et al., 2013). Meanwhile, technology-intensive MNCs from emerging economies seek to locate where there are knowledge competencies, given these are often weaker in their home economies (Crescenzi et al., 2016). Some MNCs seek access to particular markets. For example, Indian MNCs locate in developed nations to be closer to clients as their technological capabilities rise (Andreff, 2016); Japanese firms are found to take into account the uncertainties of a nation's policy environment in expansion decisions (Delios, \& Henisz, 2003); and, Chinese MNCs to use Australia as a testing ground for capacity building as its markets resemble that of the major triad economies but with a smaller economy allowing for faster feedback mechanisms (Fan et al., 2016).

In many cases, the markets of this region are considered emerging, operating according to very different dynamics than other areas of the world (Hemmert, \& Meyer-Ohle, 2014; Roca, 2018). Hemmert and Meyer-Ohle (2014) note that where emerging economies in Asia-Pacific formerly were receptors of FDI from more advanced regions, they are now FDI investors themselves with very different investment seeking behaviors. Furthermore, the socioeconomic, political and institutional diversity of these nations have fostered different industry profiles, maturities, and firm structures compared to the more established markets in Europe and the US. For many of these nations, Western laissez-faire assumptions of the invisible hand may not hold true, as firms exist within a strong developmental state, or as large conglomerate corporate traditions often linked to family structures. For example, the traditional keiretsu system in Japan interlocking corporate relations and shareholdings through centuries will influence how these corporations engage in buyer and supplier markets (Horn et al., 2010). 
Furthermore, as Buckley (1985) contends, the mercantilist model pursued by Japanese firms differs from the US model, which focuses more on factor inputs and production costs. The export-led focus of the Japanese industrialization was to some degree replicated by the Asian ‘Tigers' of Hong Kong, South Korea, Singapore and Taiwan, and more recently by China and Vietnam.

The export-led economic model was driven in South Korea by its large chaebol whose steeped family origins are linked politically (Jun et al., 2010), and for the strong social networks also known as guanxi in China (Hutching and Murray, 2002). These traditional links shape both domestic and global connections (cf. Steirer, 2009), including inhibiting or directing global expansion as is the case in the largely state-owned or influenced corporations of China. These national variations translate into different spatial patterns by sector or nation as firms globalize, for example, as shown by the energy sector in Australia (Martinus et al., 2015) or the ICT sector in India (Mir, \& Mir, 2005).

To date, research on the geographies of corporate networks in the Asia-Pacific region has been surprisingly limited (cf. Derudder et al., 2018; Horner, 2014; Lai, 2012; Yang, \& Coe, 2009; Yeung, 2014), and that on THOFC in the region has been largely confined to the fields of political economy, law, and economics (Brook, \& McGrew, 2013; Buckley et al., 2010; Fichtner, 2016). However, as the global economic center of gravity shifts toward the AsiaPacific region, so should the focus on the role of THOFC for MNCs operating there allowing a better understanding of just how global the 'tax issue' is.

\section{Tax Havens and Offshore Financial Centers}

While this and related research seeks to identify relative differences in how MNCs globalize, the fluidity of contemporary corporations implies that MNC structures are in practice much 
more complicated. One driving factor has been the rising importance of strategic tax 'optimization', and in particular transactions involving THOFC, which total approximately 15 per cent of all nations (Dharmapala, \& Hines. 2009) and mediate at least 30\% of global FDI stock (Haberly, \& Wojcik, 2015). Given the recent proliferation of papers on the topic (Haberly, \& Wójcik, 2015; Janský, \& Prats, 2015; Jones, \& Temouri, 2016; Wójcik et al., 2018), THOFC are increasingly recognized as key actors in global financial flows, processes of globalization, as well as the greater mobility of goods and services (Hong, \& Smart, 2010). While no formal definition exists, THOFC are jurisdictions offering benefits to individuals, trusts, or corporations. Their legal and regulatory frameworks often obscure ownership through opaque special purpose vehicles (SPVs) or through restrictive secrecy laws, low oversight, flexible ownership (e.g., shareholder, trustee) structures, and - most importantly - low or no tax on profits, earned income or dividends (Palan et al., 2009). Though much is known about the distribution of MNCs, considerably less is known about those operating in THOFC. Firms themselves are reluctant to reveal their corporate location strategies as many would fall into a grey area of compliance. This has meant that research on THOFC is encumbered by inadequate access to data, as well as the obvious pitfalls of surveying firms or industry experts on the subject.

As THOFC functions increase in complexity, neither 'tax havens' nor 'offshore financial centers' is an entirely accurate term. The former suggests that taxation is the only reason firms incorporate in such jurisdictions, and the latter that these are mainly small island nations (e.g., Bermuda, Vanuatu) somehow detached from the core global economies. While GarcíaBernardo et al. (2017) argue that the most significant 'offshore' financial conduits are core territorial states of the Netherlands, United Kingdom, Ireland, Singapore, and Switzerland, many THOFC are small nation-states or territorial dependencies not prominent in global rankings. One defining feature of THOFC is their outsized role in corporate structures (cf. 
Baldacchino, 2018; Briguglio, 2010). Indeed, they were central figures in the 2008/09 Global Financial Crisis as much of global investments often ended up in their jurisdictions (Palan et al., 2009).

THOFC are distinct from other 'nodes' in MNC networks as firms typically have minimal to no physical presence. They are increasingly under scrutiny (Zucman, 2015), due to their prevalence and the simplicity by which firms today transfer funds across borders compared to the past. Indeed, Cobham et al. (2015) argue that the geography of THOFC and off-shore financial flows is best understood by the level of secrecy they provide through lack of information exchange and transparency. The 'digital firm' of the new millennium can move capital and labor between countries, as well as create corporate structures highly favorable to offshoring profits. Uber, for example, is incorporated in the Netherlands and operates globally through local subsidiaries. Amazon and Paypal's European headquarters are in Luxembourg, while those of Facebook and Google are in Ireland. Taxation is further obfuscated by complex structures that direct revenues and profits offshore. Many 'American' or 'Chinese' holding companies are in fact registered in the Cayman Islands or British Virgin Islands, despite their operations being distributed primarily between North America, Europe, and Asia. National governments, as well as international organizations such as the OECD and IMF, are increasingly aware of the magnitude of the 'problem', and have begun acting to collaborate on tax harmonization and compliance issues (Forstater, 2018; Kemme et al., 2017).

In addition to the socio-political ties embedded within the geographical relations of THOFCs, firm strategies determine the selection processes. The range of such transactions is complex, with some strategies focusing on reducing taxable profits, and others on booking debts that can be written off of tax liabilities. A number of related processes are deployed within these structures, such as 'base erosion' and 'profit shifting' which 'refers to tax avoidance strategies that exploit gaps in mismatches in tax rules to artificially shift profits to low or no-tax locations' 
(OECD, 2018). Transfer pricing is a subset of profit shifting in which firms 'internally' shift revenues or profits to jurisdictions with more favorable tax conditions. Merchanting and merchandising is similar, but with another firm taking 'intermediary' ownership or possession of goods. For example, in Hong Kong, these two mechanisms alone accounted for $\$ 540$ billion in goods trade in 2016 (HKSTATD, 2018), and are related largely to tax avoidance on shipments going to or from mainland China. 'Round-tripping' and 'capital-augmentation' are other strategies, involving the transfer of funds to an offshore jurisdiction and then immediately back again. This enables anonymity and access to special 'foreign investor' tax and other concessions (Sutherland et al., 2012). Others have suggested that in many cases capital-raising takes priority over tax-related motives (Sutherland, \& Matthews, 2009).

\section{Data and Methodology}

Despite the importance of THOFC to the global network, there is limit knowledge of how they are positioned within MNC firm networks. This section details the application of network analysis to understand this within Asia-Pacific corporate networks. To this end, we treat countries as strategic 'nodes' in the global economy that mediate the redistribution of capital, information, and resources. Firms make strategic decisions to locate headquarters, branches, and/or subsidiary locations internationally in order to gain some advantage related, in this case primarily in terms of taxation.

Methodologically, we take parent-subsidiary locations and transform them into geographic ties to form MNC networks. Analyzing and comparing the emergent network structures produces insight into how locations are differentially embedded in the global economy. This approach has been most commonly applied in 'world city network' research, where a broad range of corporate datasets are used to understand the different structural positions of cities within intercity networks (e.g., Alderson et al., 2010; Hennemann, \& Derudder, 2014; Krätke, 2014; Sigler, 
\& Martinus, 2017). We adopt this approach, but as our interest is in THOFC, our geographical lens is on 'countries' rather than cities.

Five corporate networks were constructed from a database of headquarters and subsidiary national locations of firms listed on each of the five respective Asia-Pacific major stock exchanges: Australian Securities Exchange (ASX), Bombay Stock Exchange (BSE), Shanghai Stock Exchange (SSE), Shenzhen Stock Exchange (SZSE) and Tokyo Stock Exchange (TSE). Each exchange network is assumed to information on how firms of different countries globalize, with the national importance of different industries of a stock exchange reflecting a nations' dominant sector (Martinus et al., 2015).

Firm data was extracted between mid-2016 and mid-2017 to reflect all active listings on the ASX, BSE, SSE, SZSE, and TSE. Headquarter and subsidiary location data were sourced from a variety of commercially available databases, including Osiris (Bureau van Dijk), Bloomberg, Central Depository Service, and Morningstar, with subsidiaries matched to parent corporations using the International Securities Identification Number (ISIN) - a code unique to each global listing. The five exchanges together represent a total of 9451 listed firms and 193,322 subsidiaries. Approximately six per cent of these subsidiaries were identified as being located in THOFCs. Country codes were derived from firm International Securities Identification Number (ISIN) codes, the first two letters of which generally designate a 2-digit ISO country code. As a list of fully sovereign states would miss a significant proportion of the world's THOFC (e.g., Hong Kong, Bermuda), countries were designated by their ISO code. However, although British dependencies such as the Cayman Islands and BVI were included, data for the Channel Islands (Jersey and Guernsey) and Isle of Man were unavailable.

THOFC jurisdictions were identified using interrelated references to THOFCs, and related to types defined by Palan et al. (2009). Banking secrecy hubs, such as Turks and Caicos, shield their clients from having to disclose information to outside parties. Market entry conduits, such 
as the Netherlands and Ireland, provide lower tax rates compared to others within their trading bloc, notably the European Union. Incorporation centers, such as Montserrat and Panama, are places with relatively lax corporate laws, allowing clients to incorporate offshore without having bona fide local operations. Others are known for registration: for example, many of the world's shipping companies use Liberia and/or the Marshall Islands to register their vessels. There are also differences between the clients of THOFC. Monaco, Gibraltar, and Switzerland, for example, actively target high net worth individuals (HNWI), while trusts and funds operate in jurisdictions with low corporate, or capital gains, taxes, such as Luxembourg and Singapore. There are also industry-specific niches including Guernsey for insurance and reinsurance, Luxembourg for funds, and Ireland and the Netherlands as market entry conduits for large firms. In this study, THOFC were identified by one of three source lists generated by the Institute on Taxation and Economic Policy (ITEP), the OECD, or on five or more global 'watch lists' compiled by Palan et al. (2009). A total of 50 jurisdictions were included, divided almost evenly between (mostly) small nation-states, including Costa Rica, Barbados, Switzerland, Belize, and Bahrain, and smaller territorial dependencies, in large part British overseas territories and crown dependencies. These include the Cayman Islands, Jersey, Guernsey, Isle of Man, and Bermuda, among others. Large nation-states with certain sub-national tax benefits were not included, notably the United States, for which Delaware fulfils this role, and Malaysia, which includes Labuan.

Parent-subsidiary inter-country links, as the relational building blocks of each of the five network, were 'spatialized' by assigning a directed location link or tie between parent company to subsidiaries. Therefore, a link was drawn between any pair of countries when at least one parent company was located in a country with a subsidiary in the other country. For example, a Thai subsidiary to a Japanese parent company would constitute a Japan-Thailand tie. Furthermore, a weight $w_{i j}$, indicating the strength of the relationship between country $i$ and 
country $j$, was added to each link by counting parent-subsidiary pairs between correspondent nodes. For example, if a parent company located in country $i$ has three subsidiaries located in country $j$, there is a threefold increase in the weight $w_{i j}$. Finally, self-loops were removed, so that only connections given by companies having parent and subsidiaries in different countries was retained. The above procedure gave rise to five undirected weighted networks $G(\mathcal{V}, \mathcal{E})$, where $\mathcal{V}$ and $\mathcal{E}$ are, respectively, the set of $N=|\mathcal{V}|$ nodes and the set of $K=|\mathcal{E}|$ links associated to the considered stock exchange. In order to study the role of nodes within these networks and identify the key countries, three centrality measures were considered: the degree (DC), eigenvector (EC) and betweenness (BC) centrality (Latora et al., 2017). The first measure is a structural one, and it is the most basic topological characterization of a country within the network, measured in terms of number of connections (degree). More precisely, the DC of a node $i \in \mathcal{V}$ is defined as:

$$
D C_{i}=\frac{1}{N-1} \sum_{j=1}^{N} a_{i j}
$$

where $a_{i j}$ are the elements of the adjacency matrix $A \equiv\left\{a_{i j}\right\}$ of $G$, whose entries are either ones if $(i, j) \in \mathcal{E}$, or zeros otherwise. As a generalization of the DC, we considered the eigenvector centrality, which is based on the notion that connections to high-scoring nodes contribute more to the centrality of a node. In particular, for a node $i \in \mathcal{V}$, the EC is given by:

$$
E C_{i}=u_{1, i}
$$

where $u_{1, i}$ is the ith component of the eigenvector $u_{1}$ associated to the eigenvalue $\lambda_{1}$ of $A$, such that it satisfies $A u_{1}=\lambda_{1} u_{1}$. In our network specification, a high EC means that a country is connected to many countries who themselves have high scores. Betweenness centrality complements DC and EC by exploring how much 'control' a country has over the network structure as shown by the number of shortest network paths passing through it. For every pair of nodes in a connected graph, there exists at least one shortest path between the nodes, such 
that the number of links that have to be traversed in order to reach one node starting from the other is minimum. The $\mathrm{BC}$ for a node $i$ is defined by using the number of these shortest paths passing through it. In particular, for a node $i$ the betweenness centrality is given by:

$$
B C_{i}=\frac{1}{(N-1)(N-2)} \sum_{j=1 ; j \neq i}^{N} \sum_{k=1 ; k \neq i, j}^{N} \frac{n_{j k}(i)}{n_{j k}}
$$

where $n_{j k}$ is the number of shortest paths from node $j$ and node $k$, while $n_{j k}(i)$ is the number of these shortest paths containing node $i$. In addition to these three complementary centrality measures, we explore the community structure of the networks by using the Blondel algorithm (Blondel et al., 2008), while the ForceAtlas2 algorithm (Jacomy et al., 2014) ${ }^{1}$ was used to produce the final layout of the visualizations.

Eigenvector centrality, betweenness centrality, and degree centrality were all considered to better understand the overall network structures (see Appendix). However, ultimately, due to the simplicity of the BSE and SZSE in particular, degree centrality proved to be the most useful, measuring direct connections rather than intermediation (betweenness) or connectivity to other highly connected nodes (eigenvector). This remainder of this paper discusses the findings of this analysis of the five networks.

\section{Geographies of Asia-Pacific Corporate Tax Strategies}

The distribution of industry sectors varies significantly from one exchange to another in a sample of 11 of the world's largest exchanges. For example, the domination of firms in the materials and energy sectors on the ASX (figure 1) reflects Australia's strength and global competitiveness in the mining and energy sectors (Martinus et al., 2015). Similarly, the SZSE is dominated by manufacturing firms, and the BSE hosts a large number of industrials,

\footnotetext{
${ }^{1}$ This algorithm was used to preserve the central position of nodes with a high connectivity to the core. The parameter with the best trade-off regarding disposition of the node and figure readability was selected.
} 
especially in chemicals, textiles, and the like. Though somewhat similar, the key difference between the SZSE and SSE is that the former lists smaller and less well-established firms. The TSE is heavily concentrated on financials such as banks, and is distinguished by a strong presence in automobiles and components.

\section{INSERT FIGURE 1}

Each of the figures (2-6) in this section represents visually how nations are connected within each stock exchange network, with node sizes determined by degree centrality and the thickness of connecting edges denoting the tie strength between two nations. The distance of a node to other nodes relays information regarding the strength of the relationship. For example, the node at the core of the network is the primary node. Nodes closer to this node are relatively more important to the network as a great number of connections to the central node pull it relationally closer. For the 2 denser networks (ASX and TSE), we used a k-core decomposition (Alvarez-Hamelina et al., 2006) to reduce the network to 3 nested cores: with the 1-core being the full network and the 3-core the inner core of just a few nodes.

The ASX network (figure 2) appears more complex than some of the other Asia-Pacific networks, highlighting the more sophisticated corporate spatial structures as well as larger sizes of the listed firms. In terms of bridging nations, New Zealand, Bermuda, Papua New Guinea and the UK play an important role, demonstrating the importance of both geographical proximity as well as other forms of proximity generated from factors such as colonial ties (cf. Martinus, \& Sigler, 2018).

The most significant THOFCs within the network are Singapore, Hong Kong, Cayman Islands, BVI, Ireland, and the Netherlands. This likely represents a mix of strategies, including one of Asian subsidiaries of Australian firms (Singapore, Hong Kong), onshore 'conduits' (Ireland, Netherlands) of capital, and offshore 'sinks' through SPVs. Though many of the subsidiaries in Singapore and Hong Kong represent bona fide local, or at least regional, economic activities, 
the 155 Australian subsidiaries in Cayman Islands and 135 in BVI are unlikely to appear as brick-and-mortar offices for the most part. Drilling down into which specific industries are implicated, we find the sectors of financials, materials, consumer discretionary, and information technology to be the most significant. In particular, materials plays a substantial role, with various ASX firm subsidiaries in Hong Kong, Singapore, BVI, and Cyprus. Using the proportion of total inter-country connections as a proportion of outward connections, Bermuda and BVI both emerge as significant, with headquarters in the former connecting to subsidiaries in Australia, South Africa, Hong Kong and BVI, and BVI subsidiaries connecting to Australia and Papua New Guinea - in both cases related to the structures applied by mining companies such as Northwest Resources, Oklo and Nyota, and oil companies such as Oil Search and Horizon. The strong connection between China and the Cayman Islands was also apparent in the ASX, as subsidiaries of Macquarie Group including China Medical System, China Mengniu Dairy, and China State Construction were all corporates in the Caribbean jurisdiction. Several funds and mining-related companies on the ASX were also incorporated subsidiaries in Bermuda, as were holding companies for several large conglomerates including shareholders in a large global television syndicate and another holding a major hotel franchise.

The Bombay Stock Exchange (BSE) (figure 3) network is highly centralized with all listed companies connected directly to India - an indication of the lower level of globalization relative to other exchanges, as well as its strong government-led sector. It is particularly strongly connected to the USA and UK, with Indonesia, Panama and China also slightly more connected than other nations of the network. The role of THOFC was least apparent on the BSE, and likely linked to the 'degree' of globalization exercised by locally listed firms, a number of other points reinforce this observation. India's links to THOFC were primarily through subsidiaries in Singapore, UAE, Mauritius, Netherlands, and Hong Kong. Thus, unlike many of the other networks which are highly focused on the 'Bermuda Triangle' of Cayman- 
Bermuda-BVI, firms listed in India exhibited a strong preference for THOFC closer to home. In particular, both the UAE (Dubai) and Mauritius are well-known as offshore centers for Indian firms as both have a significant diaspora from the subcontinent as well as sustained commercial links.

The BSE's key industries with THOFC relations are industrials, materials, and information technology. The UAE and Mauritius are significant in all three industries, whereas subsidiaries in the Netherlands mainly are in information technology and telecommunications and health care, demonstrating the Netherlands' conduit role rather than as a sink for offshore profits. In other words, just as Ireland provides a conduit for India-listed firms in financials to Europe, the Netherlands provides favorable conditions for knowledge-intensive industries. BSE-listed firms situating in tax havens ranged in size and composition. One example is Adani, a large conglomerate known in part for its energy arm. Adani has fully-owned subsidiaries in the UAE, Mauritius, Singapore, US and Australia. Another is Fortis, one of India's largest healthcare providers, which has subsidiaries in Mauritius, BVI, Cayman Islands, UAE, Macao, and Hong Kong, among others. Thus, although these are nominally MNCs, their activities follow relatively specific patterns where their operational entities (e.g., mines, hospitals) are financially separated from arms-length firms.

The SSE (figure 4) and particularly SZSE (figure 5) network structures demonstrate a low level of globalization compared to the firms of other stock exchanges. This is largely due to the stateowned nature of the majority of Chinese industries, as well as the fact that many of the listed corporations are relatively new to market and are not yet deeply embedded in foreign markets. In SSE, China has moderately stronger connections to the USA compared to SZSE where it is very strongly connected to the USA, Germany and India.

Both SSE and SZSE display China's strong connection to Hong Kong, serving as an important entrepôt for Chinese goods, labor, and capital. In Chinese corporate structures, the Cayman 
Islands or BVI play an important role in circumventing certain "imperfections" (Buckley et al., 2013) in the Chinese capital market (Xiao, 2004). Furthermore, as Fichtner (2016) adds, "Chinese MNEs have been found to channel direct investment through OFCs (directly and also indirectly via Hong Kong) not only to minimize taxes ('round-tripping') but also to conceal the ownership of assets and to gain access to foreign capital markets" (p.1046).

The SSE-listed firms are intensely concentrated in Hong Kong, with significant numbers in Singapore, BVI, Cayman Islands, and Liberia. Unlike the other exchanges, which exhibit relative diversity, 97 percent of THOFC activity is linked to the top 10 jurisdictions, which also include Macao, the Netherlands, Bermuda, Switzerland and Luxembourg. Hong Kong-based subsidiaries are especially prevalent in the industrials, financials, energy, consumer discretionary, materials, information technology, and real estate sectors. Singapore is designated as a subsidiary location in industrials, real estate, financials, and materials, while Liberian structures are mainly in energy. The BVI is much more significant on the SSE than the Cayman Islands, notably in information technology, financials and real estate. Thus subsidiaries of knowledge intensive industries are structured directly in sink tax havens, while industrials and extractive industries more likely use Hong Kong as a conduit. The large involvement of Chinese business in the BVI reflects both a path dependency in investing there, as well as the active lobbying of Hong Kong businesses by the BVI during the British handover to China in 1997. More recently, the BVI has offered Hong Kong residents access to a special registry and Chinese-language services to set up BVI companies remotely. The subsequent increase in Hong Kong business has encouraged further Mainland Chinese investment, a large amount which is round-tripped (Shaxson, 2014).

The SZSE network is fairly similar to SSE in that Hong Kong is by far its most significant THOFC connection, albeit more focused on information technology. Singapore also features prominently as a THOFC in SZSE network, with strong connections to firms in industrials, 
materials and information technology. Like the SSE, the BVI are the most significant 'offshore' jurisdiction, particularly important in consumer discretionary and information technology. The strong IT orientation of SZSE-listed firms translates to slightly higher connectivity to European conduits in the Netherlands, Switzerland, and Belgium. For example, companies such as mobile phone producer LTE and solar energy firms such as Jiangsu Zhongli and Zhejiang Sunflower locate in Switzerland as market conduits to access capital and strong intellectual property laws.

The Tokyo Stock Exchange is sophisticated and complex, reflecting several decades of highly globalized industrialization (Figure 6). TSE also demonstrates a regionalization towards the Asia-Pacific - albeit slightly lower than that of the ASX - as well as listings of firms from the Americas and Middle East. Strong connections to China, Thailand, Taiwan, and India confirm the TSE's Asian orientation, with Japanese firms strongly embedded within regional industry. TSE's primary THOFC connection are to firms registered in Singapore, Hong Kong, the Netherlands, Cayman Islands and Bermuda. Due to the nature of Japanese industry, these connections are primarily in industrials and information technology. Subsidiaries in the Cayman Islands, Bermuda, Ireland, and Luxembourg are strongest in financials, reflecting their advantages as sinks. TSE exhibits more subsidiaries, and more connectivity to THOFC than other exchanges, and is less concentrated in particular hubs (e.g., Singapore, Hong Kong, BVI) than other exchanges.

Given the size of the TSE, a large number of non-Japanese firms also list in Tokyo. Consider the case of Bank of America, which was listed both on the NASDAQ as well as the TSE (now de-listed). The bank's Tokyo listing had a total of 3839 subsidiaries, many of which were partial stakes in large and well-known companies such as Yahoo!, Nordstrom, and Starwood hotels. This comprised subsidiaries in 48 countries, of which 83 percent were registered in the US. A large number of these subsidiaries were also located in THOFCs, including the Cayman 
Islands (86) and Bermuda (37). The four most significant subsidiary locations in continental Europe were the Netherlands, Ireland, Luxembourg, and Switzerland, respectively. Thus, while it is nearly impossible to know the logic behind any given structure, the overall pattern is consistent with other firms listed on the TSE.

\section{Discussion}

Each of the five networks present similarities and differences in the way nations both globalize and engage with tax evasion or secret activities. Firms in Australia and Japan have significantly more complex corporate structures than those in India and China, through there appears to be little variation in the degree of engagement with THOFC across the five. Thus, it is the geographical distribution of each exchange's THOFC connectivities that differ, with Chinese exchanges structured more directly through Hong Kong and the 'Bermuda Triangle' of BVIBermuda-Caymans. The hub and spoke 'star' shape of the three China and India network speaks to their highly centralized or command-and-control approach to globalization and international market penetration. Further, the overly strong influence of the Chinese state limits not only the degree to which companies globalize, but also how this globalization plays out geographically. As Buckley et al. (2013) state, "the most important reason for Chinese firms to specifically favor the Cayman Islands as a base for their listing vehicles is that it allows them to minimize their costs of raising capital" (p.115). Thus, the relative prevalence of the Hong Kong-BVI-Cayman triad evinces a relatively straightforward pattern in the majority of Chinese cases. This suggests that the drivers underlying THOFC activity may have to do with capital raising more than tax avoidance, as others have suggested.

Tied to the geopolitical story embedded in the networks is the strong regionalization of the stock exchanges supporting the case that geography matters in explaining how the off-shore world is globally networked through firm structures (Haberly, \& Wójcik, 2015). The 
connectivity of Indian firms to the UAE and Mauritius is clearly linked to socio-historical linkages, as well as Dubai's recent rise as a regional intermediary in the case of the former (Sigler, 2013). Australia-based firms have a small but significant number of subsidiaries in Vanuatu, Solomon Islands and Samoa. Hong Kong's physical proximity to mainland China is no doubt influential in its strong role in the SSE and SZSE market listings. Singapore's position is reinforced both by its role as a contemporary Asian 'global city' and as a former British colonial port with a significant Chinese diasporic population. Together, these embedded network geographies support Haberly and Wójcik (2015) arguments regarding the existence of 'regional blocks and imperial legacies' in the global offshore network. The five networks corroborate their findings regarding a 'core' comprised of the 'Bermuda Triangle' plus the four or five most prevalent European conduits, supplemented by regional specificities that are influenced by sector - such as mining in Australia - or socio-cultural ties.

Nonetheless, other findings suggest circuits of capital follow alternative forms of proximity. A large number of identified THOFC are current or former British dependencies of one kind or another, and it has been suggested common frameworks - such as the application of common law - may be a reason. Another reason may be the economic profile of Asia-Pacific listed firms, which represent the region's global industrial role more so than the service economies of North America and Europe. The fact that Shenzhen's information technology firms are so active in establishing THOFC subsidiaries suggests a future trend, particularly toward conduits with strong IP rights. Furthermore, as Jones and Temouri (2016) note, MNCs "classified as being located in liberal market economies (LMEs) are more likely to undertake tax haven activity compared with MNEs from coordinated market economies (CMEs)" (p. 238).

\section{Conclusion}

This paper adds a network dimension to locational theories on MNC strategy to explain how THOFC are integrated into the structures of firms listed in the Asia-Pacific region. Drawing 
upon data from the five stock exchanges, it focusses on THOFC as 'nodes' within global corporate networks. Two key findings are extracted from the resulting analysis. First, we corroborate previous research that THOFC are embedded within a broad range of global firm activities, and that on one hand the degree to which is determined by structural forces. Across all five exchanges there was a significant presence of THOFC, which García-Bernardo (2017) roughly categorizes as conduits, sinks, and hybrids. Conduits such as the Netherlands, Switzerland and Ireland were prevalent in each network, particularly within the financials and information technology sectors. This suggests a strong role as market entry conduits, particularly into the European Union. Singapore also served as a regional conduit in all networks. Sinks including the 'Bermuda Triangle' were observed in every network, and it is hypothesized that if second-order subsidiaries (e.g., subsidiaries of subsidiaries) had been examined, more such structures would have emerged. It is likely that as newer THOFC become more sophisticated, they will to some degree displace more developed ones such as Bermuda and Panama.

Second, geographical variation within the networks is on the other hand explained by the logics of firm strategy, and motives for MNC activity (national context and firm strategies). This adds to the internationalization literature within IB, as THOFC activity is derived from firm-specific advantages relating to tax and regulatory frameworks rather than the frequently cited factors of cheap labour, access to markets, access to knowledge, etcetera. Regional patterns are observed to some degree, particularly in the case of BSE-listed firms in UAE and Mauritius. Further, it finds that the variety of capitalism also plays a role in how firms globalize through THOFCs. Chinese firms almost invariably structure themselves through Hong Kong, with a common connection to the Cayman Islands or BVI. Whereas European strategies tend to rest on 'treaty shopping' - Switzerland providing the advantage of being outside the EU for compliance purposes, and Luxembourg, Ireland, and Netherlands within it. Access to capital is also critical, 
with Chinese firms raising funds through overseas subsidiaries. In sum, no one strategy fits each company profile, but certain commonalities suggest a combination of regulatory and tax arbitrage lead to outcomes that are strongly shaped by geography and history. This becomes apparent when firm locational decisions were aggregated into their respective networks, and resultant structures were analyzed.

Indeed, as Jones and Temouri (2016) suggest, variety of capitalism matters more than tax rates and this is generally true based on industrial and geographical variation. India's highly regulated domestic sector exhibits THOFC connectivities primarily through its large MNCs, contrasting starkly with Australia's highly globalized materials and energy sectors, whose THOFC connections are well-established. And despite the nominally socialist orientation of the Chinese state or the strong relationship between Japan's industrial and financial sectors, we provide evidence that firms across a variety of geographical contexts pursue common corporate strategies that incorporate THOFC.

Finally, we argue that it is important to consider the novel ways in which THOFC activity might diverge from previous modes and motives - particularly as East Asian export-led models become increasingly significant on a global scale. Further, as new digital platforms (e.g. the sharing economy) and payment mechanisms (e.g. cryptocurrencies) enable increasing ease in cross-border financial transactions, understanding the role of THOFC is a vital step toward cogent and viable policy solutions to support firm activity while curbing irregular flows.

\section{References}

Aalbers, M. (2018). Financial geography I: Geographies of tax. Progress in Human Geography, 1-12. doi: https://doi.org/10.1177/0309132517731253

Alderson, A., Beckfield, J., \& Sprague-Jones, J. (2010). Intercity relations and globalization: the evolution of the global urban hierarchy, 1981-2007. Urban Studies, 47(9), 1899-1923. 
Alstadsæter, A., Johannesen, N., \& Zucman, G. (2018). Who owns the wealth in tax havens? Macro evidence and implications for global inequality. Journal of Public Economics, 162, 89100 .

Alvarez-Hamelina, I., Dall'Astaa, L., Barrata. A., \& Vespignani, A. (2006). K-Core decomposition: A tool for the visualization of large scale networks. Advances in Neural Information Processing Systems 18, 41.

Andreff, W. (2016). Outward foreign direct investment form BRIC countries. Comparing the strategies of Brazilian, Russian. Indian and Chinese multinational companies. The European Journal of Comparative Economies, 12(2), 79-131.

Baldacchino, G. (2018). Mainstreaming of the study of small states and territories. Small States and Territories, 1(1), 3-16.

Blondel, V., Guillaume, J-L., Lambiotte, R., \& Lefebvre, E. (2008). Fast unfolding of communities in large networks. Journal of Statistical Mechanics: Theory and Experiment, 10, P10008.

Brook, C., \& McGrew, A. (2013). Asia-Pacific in the New World Order. London: Routledge.

Briguglio, L. (2010). Small States and the European Union: Economic Perspectives. London: Routledge.

Buckley, P. (1985) A critical view of theories of the multinational enterprise. In: Buckley, P. and Casson, M., The Economic Theory of the Multinational Enterprise, 1-19. London: Palgrave Macmillan.

Buckley, P., Cross, A., Forsans, N., \& Horn, S. (2010). The rise of the Asian multinational firm. Asian Business \& Management, 9(3), 293-297.

Buckley, P., Sutherland, D., Voss, H., \& El-Gohari, A. (2013). The economic geography of offshore incorporation in tax havens and offshore financial centers: the case of Chinese MNEs. Journal of Economic Geography, 15(1), 103-128.

Caves, R. (1974). Multinational firms, competition, and productivity in host-country markets. Economica, 41(162), 176-193.

Cobham, A., Jansky, P., \& Meinzer, M. (2015). The financial secrecy index: shredding new light on the geography of secrecy. Economic Geography, 91(3), 281-303.

Coe, N., Hess, M., Yeung, H., Dicken, P., \& Henderson, J. (2004). 'Globalizing' regional development: a global production networks perspective. Transactions of the Institute of British Geographers, 29(4), 468-484.

Crescenzi, R., Pietrobelli, C., \& Rabellotti, R. (2016). Regional strategic assets and the location strategies of emerging countries' multinationals in Europe. European Planning Studies, 24(4), 645-667.

Damgaard, J., Elkjaer, T., \& Johannsen, N. (2018). Piercing the veil. Finance and Development, 55(2), 51-53

Delios, A., \& Henisz, W. (2003). Political hazards, experience, and sequential entry strategies: the international expansion of Japanese firms, 1980-1998. Strategic Management Journal, 24(11), 1153-1164.

Derudder, B., Cao, Z., Liu, X., Shen, W., Dai, L., et al. (2018). Changing connectivity of Chinese cities in the World City Network, 2010-2016. Chinese Geographical Science, 28(2), 183-201. 
Desai, M., \& Dharmapala, D. (2006). Corporate tax avoidance and high-powered incentives. Journal of Financial Economics, 79(1), 145-179.

Dharmapala, D., \& Hines, J. (2009). Which countries become tax havens?. Journal of Public Economics, 93(9-10), 1058-1068.

Dicken, P. (2011). Global Shift: Mapping the Changing Contours of the World Economy (6 $6^{\text {th }}$ ed). New York: The Guilford Press.

Dunning, J. (2001). The eclectic (OLI) paradigm of international production: past, present and future. International Journal of the Economics of Business, 8(2), 173-190.

Dunning, J. (2014). Location and the multinational enterprise: a neglected factor?. In Location of International Business Activities, pp. 35-62. London: Palgrave Macmillan.

Dunning, J., \& Lundan, S. (2008). Multinational Enterprises and the Global Economy. Cheltenham: Edward Elgar.

Fan, D., Cui, L., Li, Y., \& Zhu, C. (2016). Localized learning by emerging multinational enterprises in developed host countries: a fuzzy-set analysis of Chinese foreign direct investment in Australia. International Business Review, 25(1A), 187-203.

Fichtner, J. (2016). The anatomy of the Cayman Islands offshore financial center: AngloAmerica, Japan, and the role of hedge funds. Review of International Political Economy, 23(6), 1034-1063.

Forsgren, M. (2013). Theories of the Multinational Firm: A Multidimensional Creature in the Global Economy $\left(2^{\text {nd }} E d\right)$. Cheltenham: Edward Elgar.

Forstater, M. (2018). Tax and development: new frontiers of research and action. CGD Policy Paper, 118.

Garcia-Bernardo, J., Fichtner, J., Takes, F., \& Heemskerk, E. (2017). Uncovering offshore financial centers: conduits and sinks in the global corporate ownership network. Scientific Reports, 7(6246), 1-10.

Guo, C., \& Lv, P. (2018). Network position of independent director in cross-border mergers and acquisitions. International Journal of Emerging Markets, 13(1), 118-135.

Grant, R., \& Nijman, J. (2002) Globalization and the corporate geography of cities in the lessdeveloped world. Annals of the Association of American Geographers, 92(2), 320-340.

Haberly, D., \& Wójcik, D. (2015). Regional blocks and imperial legacies: mapping the global offshore FDI network. Economic Geography, 91(3), 251-280.

HKSTATD. (2018). Offshore Trade in Goods. Retrieved from:https://www.censtatd.gov.hk/hkstat/sub/so454.jsp

Hemmert, M., \& Meyer-Ohle, H. (2014). Outward globalization and collaboration in Asia: revisiting the global business landscape. Asian Business \& Management, 13(3), 191-195.

Hennemann S., \& Derudder, B. (2014). An alternative approach to the calculation and analysis of connectivity in the world city network. Environment and Planning B, 41(3), 392-412.

Hong, Q., \& Smart, M. (2010). In praise of tax havens: international tax planning and foreign direct investment. European Economic Review 54(1), 82-95.

Horn, S., Forsans, N., \& Cross, A. (2010). The strategies of Japanese firms in emerging markets: the case of the automobile industry in India. Asian Business \& Management, 9(3), 341-378. 
Horner, R. (2014). Strategic decoupling, recoupling and global production networks: India's pharmaceutical industry. Journal of Economic Geography, 14(6), 1117-1140.

Hutching, K., \& Murray, G. (2002). Australian expatriates' experiences in working behind the Bamboo Curtin: an examination of guanxi in post-Communist China. Asian Business \& Management, 1(3), 373-393.

Jacomy, M., Venturini, T., Heymann, S., \& Bastian, M. (2014). ForceAtlas2, a continuous graph layout algorithm for handy network visualization designed for the Gephi software. PLoS One, 9(6), e98679.

Janský, P., \& Prats, A. (2015). International profit-shifting out of developing countries and the role of tax havens. Development Policy Review, 33(3), 271-292.

Jones, C., \& Temouri, Y. (2016). The determinants of tax haven FDI. Journal of World Business, 51(2), 237-250.

Jun, I., Sheldon, P., \& Rhee, J. (2010). Business groups and regulatory institutions: Korea's chaebols, cross-company shareholding and the East Asian crisis. Asian Business \& Management, 9(4), 499-523.

Kemme, D., Parikh, B., \& Steigner, T. (2017). Tax havens, tax evasion and tax information exchange agreements in the OECD. European Financial Management, 23(3), 519-542.

Kim, Y., \& Gray, S. (2017). Internationalization strategy and the home-regionalization hypothesis: the case of Australian multinational enterprises. Australian Journal of Management, 42(4), 673-691.

Kratke, S. (2014). Global pharmaceutical and biotechnology firms' linkages in the world city network. Urban Studies, 51(6), 1196-1213.

Lai, K. (2012). Differentiated markets: Shanghai, Beijing and Hong Kong in China's financial center network. Urban Studies, 49(6), 1275-1296.

McCarthy, K., \& Dolfsma, W. (2016). Market performance: liquidity or knowledge? Evidence from the market for corporate control. In: Hanappi, H., Katsikides, S., \& Scholz-Wäckerle, M. (Eds.) Theory and Method of Evolutionary Political Economy, pp.115-126. London: Routledge.

Markusen, J. (1995). The boundaries of multinational enterprises and the theory of international trade. Journal of Economic Perspectives, 9(2), 169-189.

Martinus, K., Sigler, T., Searle, G., \& Tonts, M. (2015). Strategic globalizing centers and subnetwork geometries: a social network analysis of multi-scalar energy networks. Geoforum, $64,78-89$.

Martinus, K., \& Sigler, T. (2018). Global city clusters: theorizing spatial and non-spatial proximity in inter-urban firm networks. Regional Studies, 52(8), 1041-1052.

Mir, R., \& Mir, A. (2005). Catalysis, not leapfrog: an institutionalist argument for a limited role of ICTs in India's development. Asian Business \& Management, 4(4), 411-429.

OECD (2018) Base erosion and profit sharing [website]. Available at: http://www.oecd.org/tax/beps/

Palan, R., Murphy, R., \& Chavagneux, C. (2009). Tax Havens: How Globalization Really Works. Ithaca, NY: Cornell University Press. 
Peck, J., Brenner, N., \& Theodore, N. (2018). Chapter 1: Actually existing neoliberalism. In D. Cahill, M. Cooper, M. Konings \& D. Primrose (Eds.) The SAGE Handbook of Neoliberalism: (pp.3-15), London: Sage.

Roberts, S. (1995). Small place, big money: The Cayman Islands and the international financial system. Economic Geography, 71(3), 237-256.

Robinson, J. (2002). Global and World Cities: a view from off the map. International Journal of Urban and Regional Research, 26(3), 531-554.

Roca, E. (2018). Price Interdependence Among Equity Markets in the Asia-Pacific Region: Focus on Australia and ASEAN. NY, NY: Routledge.

Rugman, A., \& Verbeke, A. (2004). A perspective on regional and global strategies of multinational enterprises. Journal of International Business Studies, 35(1), 3-18.

Schotter, A., Mudambi, R., Doz, Y., \& Gaur, A. (2017). Boundary spanning in global organizations. Journal of Management Studies, 54(4), 403-421.

Shaxson, N. (2014). China Leaks: how the BVI became China's foreign tax haven of choice. Tax Justice Network, January 14. Retrieved from: https://goo.gl/phbPny

Short, J. (2004). Black holes and loose connections in the global urban network. The Professional Geographer, 56(2), 295-302.

Sigler, T. (2013). Relational cities: Doha, Panama City, and Dubai as 21st century entrepôts. Urban Geography, 34(5), 612-633.

Sigler, T., \& Martinus, K. (2017). Extending beyond 'world cities' in World City Network (WCN) research: urban positionality and economic linkages through the Australia-based corporate network. Environment and Planning A, 49(12), 2916-2937.

Steier, L. (2009). Familial capitalism in global institutional contexts: implications for corporate governance and entrepreneurship in East Asia. Asia Pacific Journal of Management, 26(3), 513-535.

Sutherland, D., \& Matthews, B. (2009). 'Round Tripping' or 'Capital Augmenting' OFDI?: Chinese outward investment and the Caribbean tax havens. Paper prepared for Leverhulme Centre for Research on Globalisation and Economic Policy (GEP), University of Nottingham, 14-15 Jan.

Sutherland, D., Matthews, B., \& El-Gohari, A. (2012). An exploration of how Chinese companies use tax havens and offshore financial centers: 'round-tripping' or 'capitalaugmenting OFDI? In: X. Fu (Ed) China's Role in Global Economic Recovery. eBook ISBN: 9781136632495 .

Taylor, P., \& Derudder, B. (2018). World City Network: A Global Urban Analysis. NY, NY: Routledge.

Taylor, P., Derudder, B., Hoyler, M., \& Ni, P. (2013). New regional geographies of the world as practised by leading advanced producer service firms in 2010. Transactions of the Institute of British Geographers, 38(3), 497-511.

Taylor, P., Derudder, B., Faulconbridge, M., Hoyler, M., \& Ni, P. (2014). Advanced producer service firms as strategic networks, global cities as strategic places. Economic Geography, 90(3). 267-291.

Vedel, M., \& Servais, P. (2017). More than just one middleman: on the value of differenct entry modes by SMEs in foreign markets. In: Marinova, S., Larimo, J., \& Nummela, N. (Eds) Value Creation in International Business, pp.151-170. London: Palgrave Macmillan. 
Wall, R., \& van der Knaap, G. (2011). Sectoral differentiation and network structure within contemporary worldwide corporate networks. Economic Geography, 87(3), 267-308.

Williamson, P., \& Yin, E. (2014). Accelerated innovation: The new challenge from China. MIT Sloan Management Review, 55(4), 27.

Wójcik, D. (2013). Where governance fails: Advanced business services and the offshore world. Progress in Human Geography, 37(3), 330-347.

Wójcik, D., Knight, E., \& Pažitka, V. (2018). What turns cities into international financial centers? Analysis of cross-border investment banking 2000-2014. Journal of Economic Geography, 18(1), 1-33.

Xiao, G. (2004). People's Republic of China's Round-Tripping FDI: Scale, Causes and Implications (No. 7). ADB Institute Discussion Papers.

Yang, D., \& Coe, N. (2009). The governance of global production networks and regional development: a case study of Taiwanese PC production networks. Growth and Change, 40(1), $30-53$.

Yeung, H. (2014). Governing the market in a globalizing era: developmental states, global production networks and inter-firm dynamics in East Asia. Review of International Political Economy, 21(1), 70-101.

Yeung, H., \& Coe, N. (2015). Toward a dynamic theory of global production networks. Economic Geography, 91(1), 29-58.

Zucman, G. (2015). The Hidden Wealth of Nations: The Scourge of Tax Havens. Chicago: University of Chicago Press. 
Figure 1: Industry composition of each stock exchange
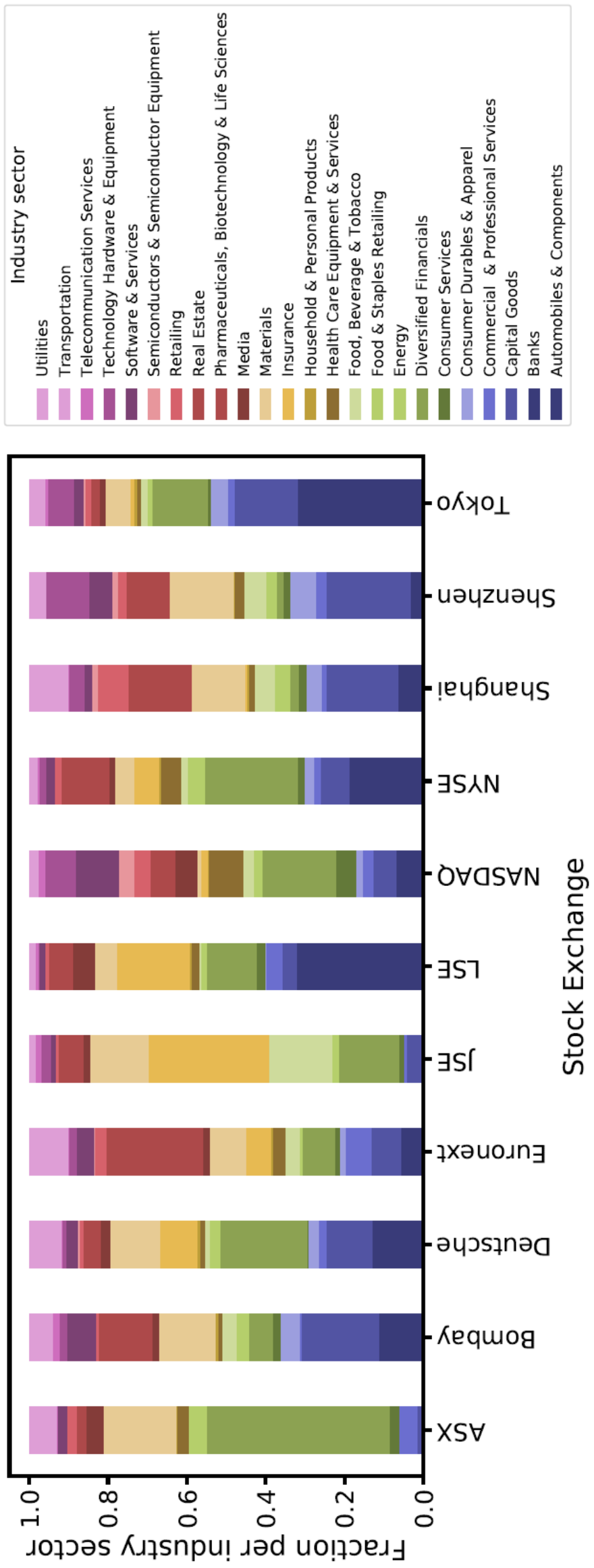


\section{Figure 2: ASX Network}

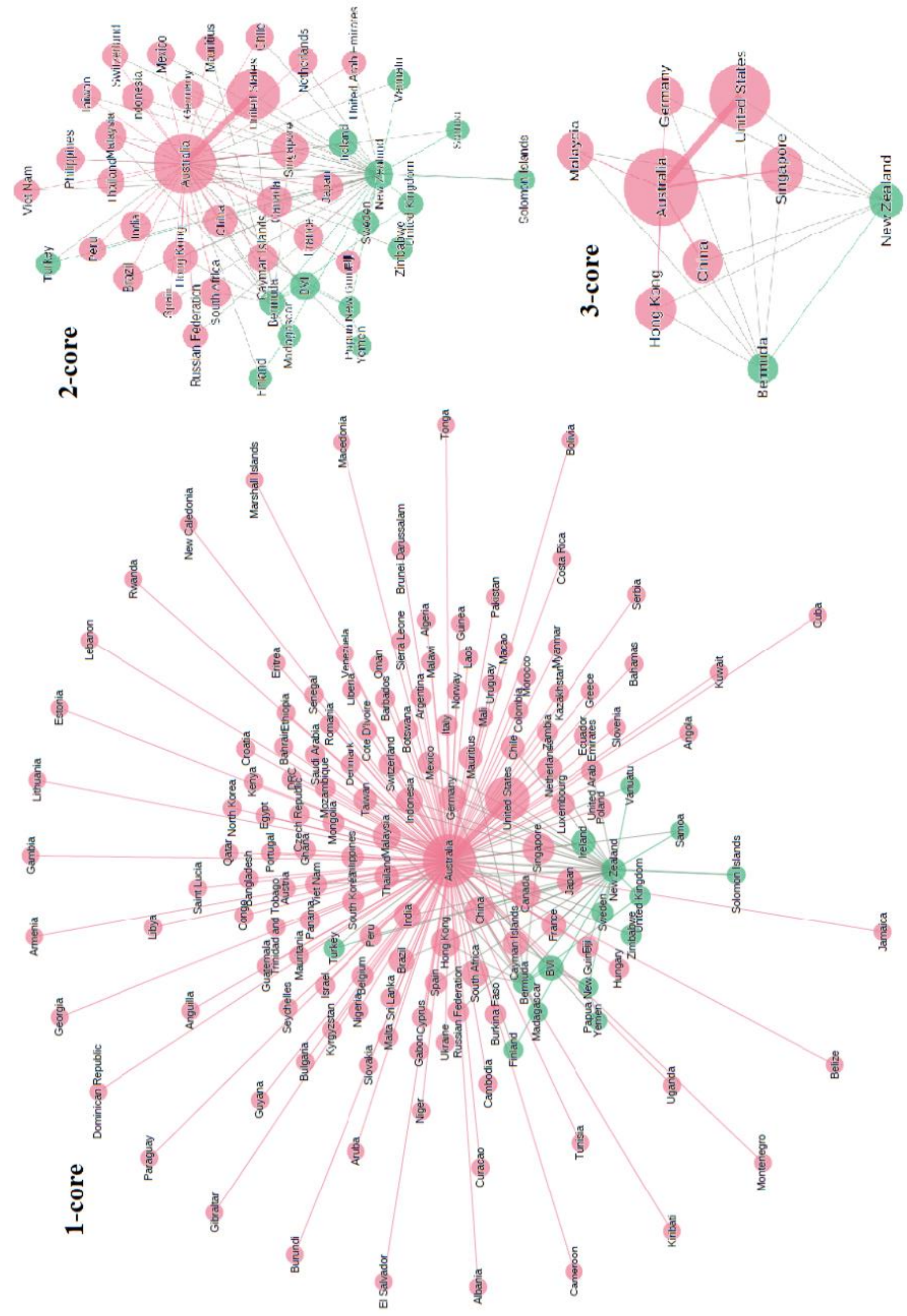




\section{Figure 3: Bombay Network}

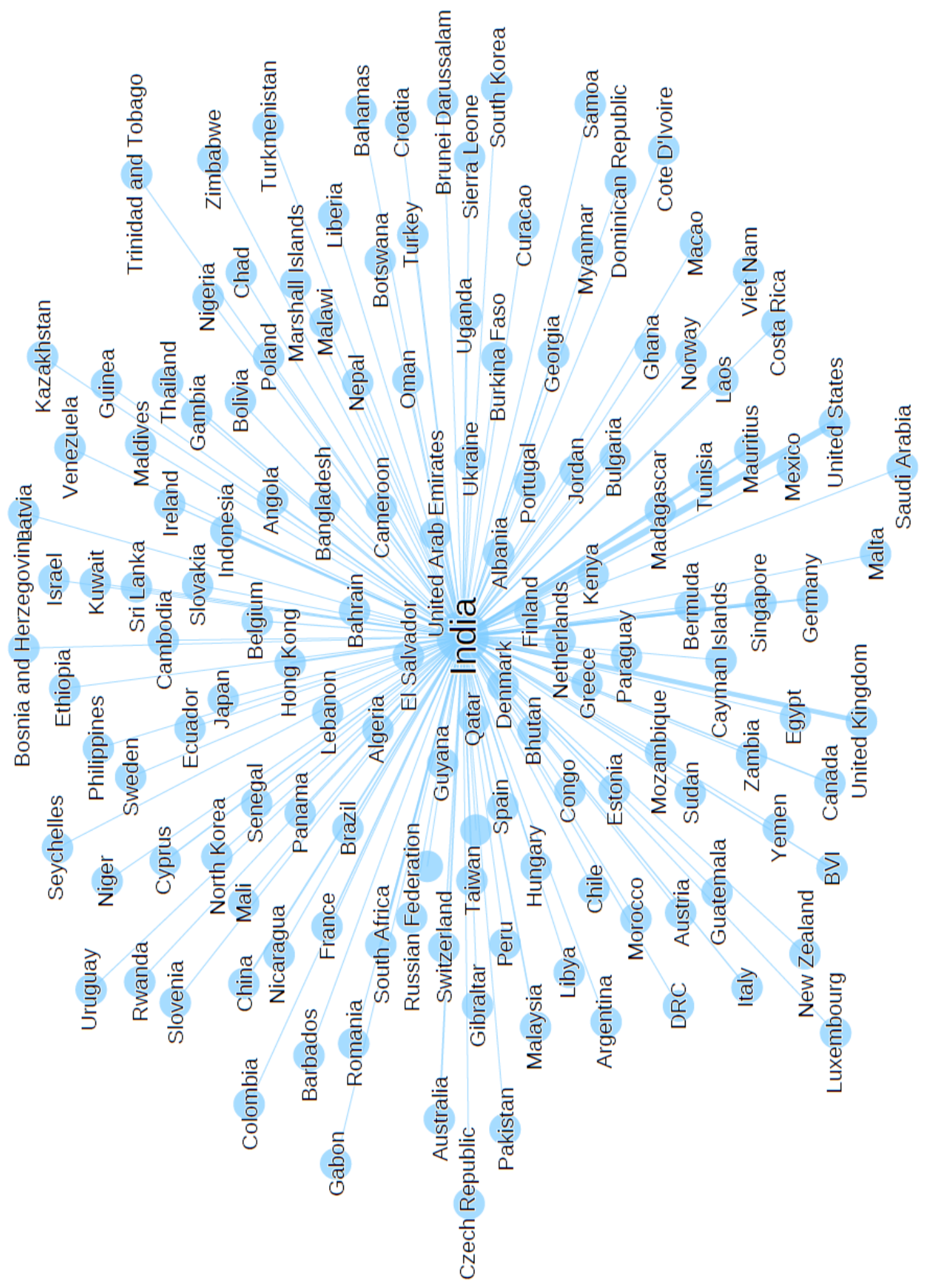




\section{Figure 4: Shanghai Network}

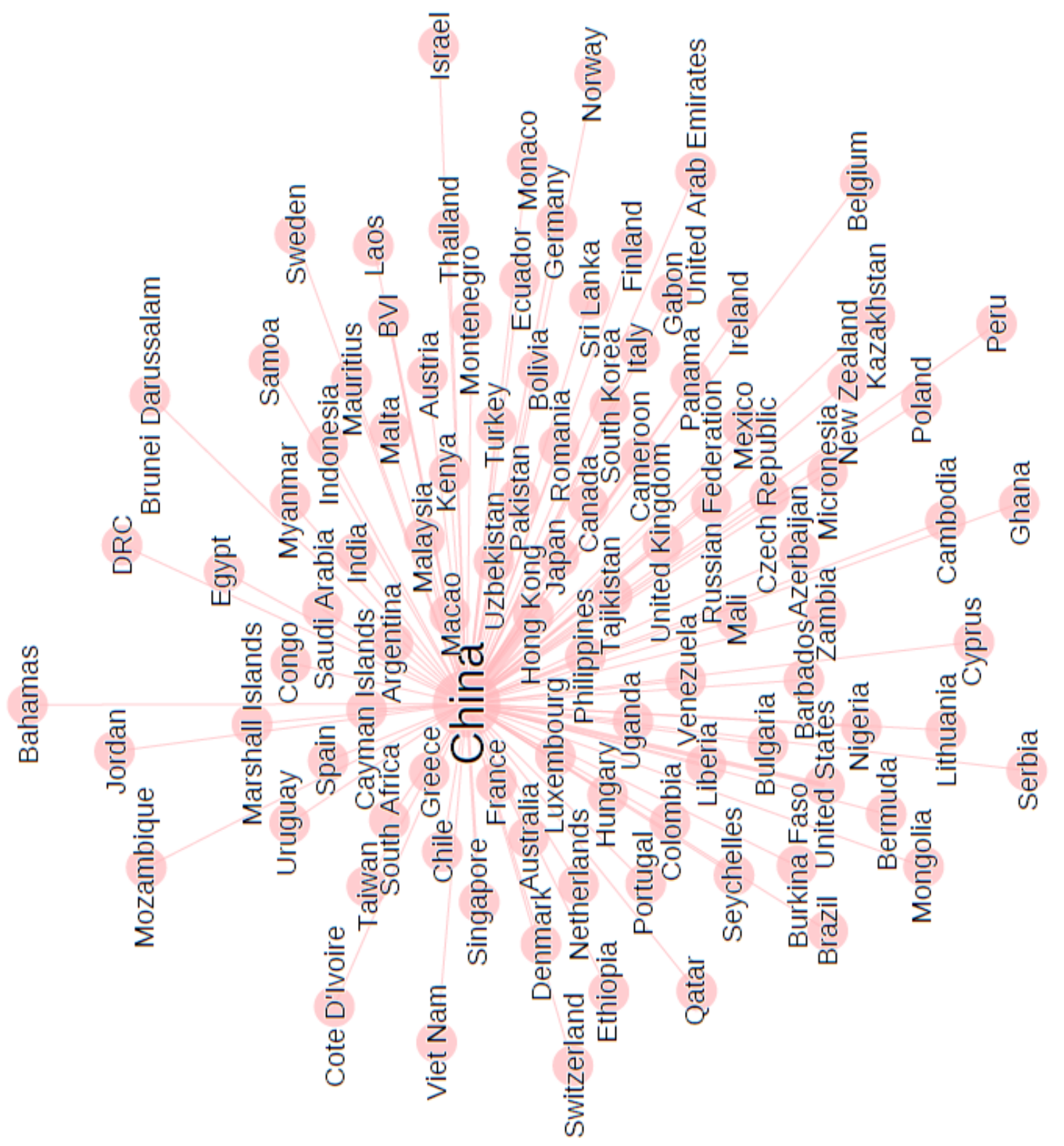




\section{Figure 5: Shenzhen Network}

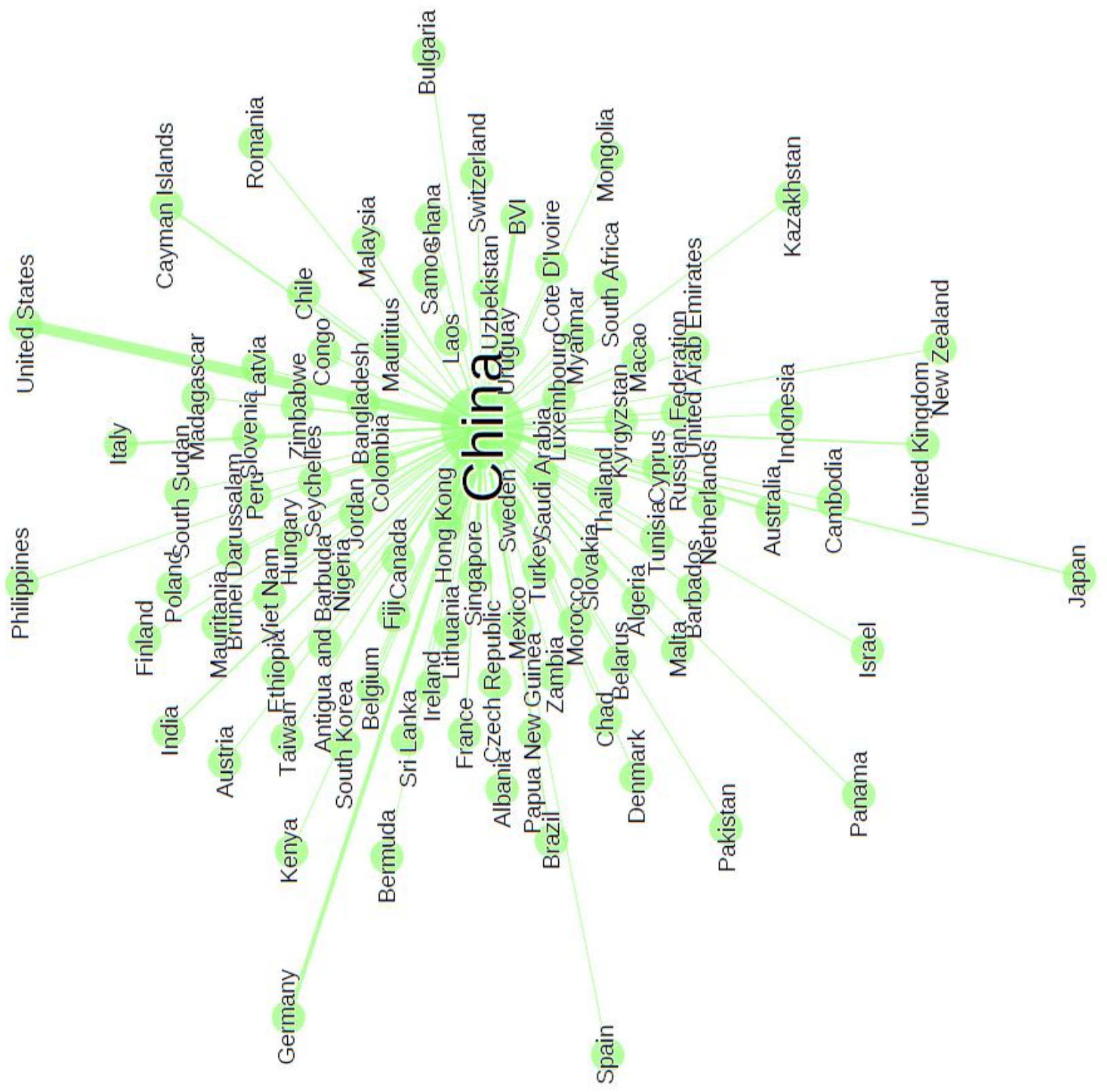


Figure 6: Tokyo Network

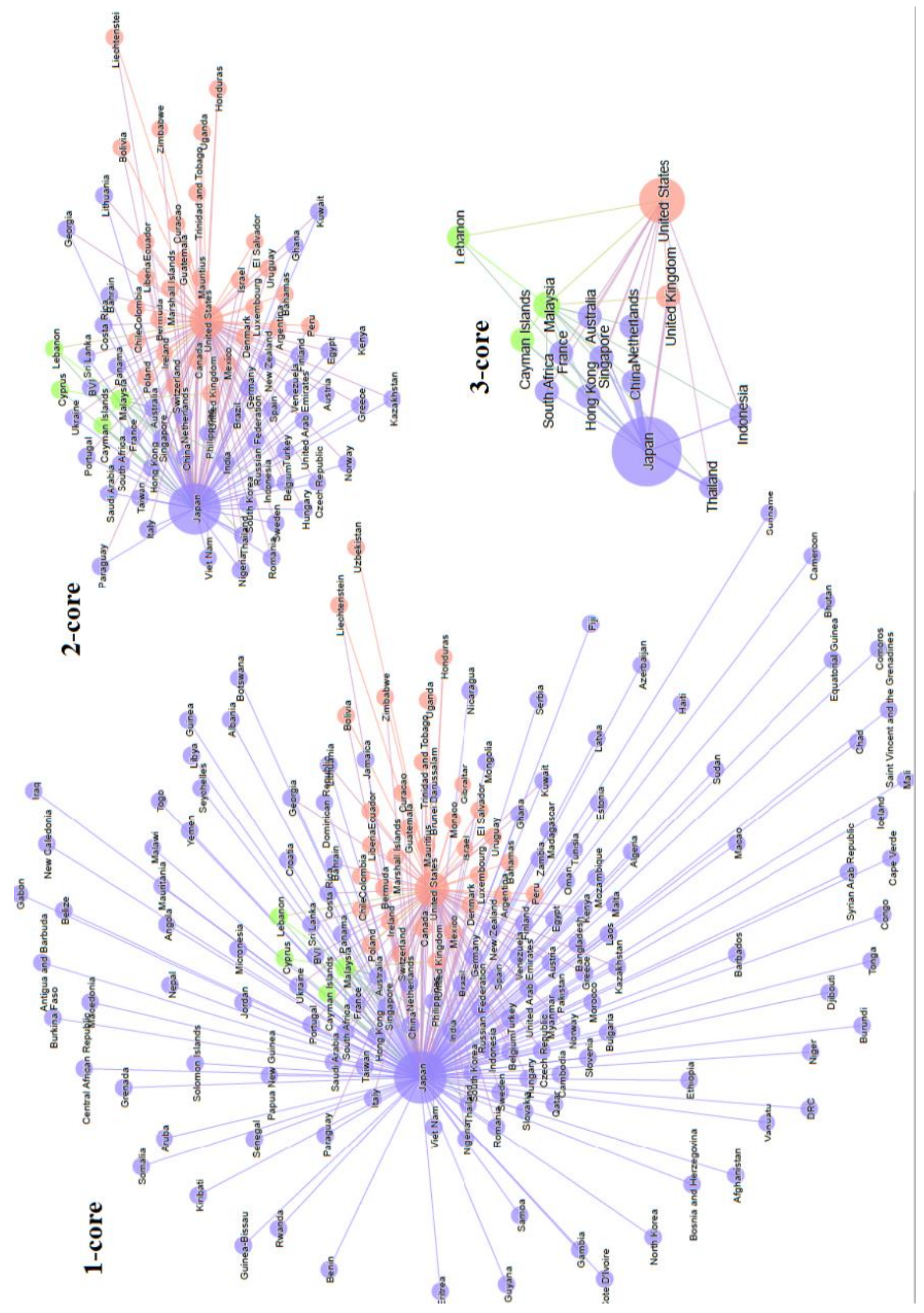


APPENDIX - DATA: Top 25 Network Metrics for Five Asia-Pacific Stock Exchanges: ASX, TSE, SSE, SZSE and BSE

\begin{tabular}{|c|c|c|c|c|c|c|c|c|c|c|c|c|c|c|c|c|c|c|c|}
\hline \multirow[t]{2}{*}{ ASX } & \multirow[b]{2}{*}{$\mathrm{BC}^{2}$} & \multirow[b]{2}{*}{ DC } & \multirow[b]{2}{*}{ EC } & \multicolumn{4}{|l|}{ TSE } & \multirow[t]{2}{*}{ SSE } & \multirow[b]{2}{*}{$\mathrm{BC}$} & \multirow[b]{2}{*}{ DC } & \multirow[b]{2}{*}{$\mathrm{EC}$} & \multicolumn{4}{|l|}{ SZSE } & \multicolumn{2}{|l|}{ BSE } & \multirow[b]{2}{*}{ DC } & \multirow[b]{2}{*}{ EC } \\
\hline & & & & & $\mathrm{BC}$ & DC & $\mathrm{EC}$ & & & & & & $\mathrm{BC}$ & DC & EC & & $\mathrm{BC}$ & & \\
\hline Australia & 96.77 & 1.00 & 0.67 & Japan & 87.59 & 0.98 & 0.60 & China & 1.00 & 1.00 & 0.71 & China & 1.00 & 1.00 & 0.71 & India & 1.00 & 1.00 & 0.71 \\
\hline $\begin{array}{r}\text { New } \\
\text { Zealand }\end{array}$ & 2.53 & 0.24 & 0.25 & USA & 13.39 & 0.47 & 0.38 & UAE & & 0.01 & 0.07 & UAE & & 0.01 & 0.07 & UAE & & 0.01 & 0.06 \\
\hline Bermuda & 0.23 & 0.09 & 0.13 & Malaysia & 0.19 & 0.08 & 0.12 & Argentina & & 0.01 & 0.07 & $\begin{array}{r}\text { Antigua \& } \\
\text { Barbuda }\end{array}$ & & 0.01 & 0.07 & Albania & & 0.01 & 0.06 \\
\hline $\begin{array}{r}\text { Papua New } \\
\text { Guinea }\end{array}$ & 0.02 & 0.03 & 0.08 & Hong Kong & & 0.02 & 0.08 & Austria & & 0.01 & 0.07 & Albania & & 0.01 & 0.07 & Angola & & 0.01 & 0.06 \\
\hline UK & 0.01 & 0.03 & 0.08 & Cayman & & 0.02 & 0.08 & Australia & & 0.01 & 0.07 & Austria & & 0.01 & 0.07 & Argentina & & 0.01 & 0.06 \\
\hline B.Virgin Is. & & 0.02 & 0.07 & Australia & & 0.02 & 0.07 & Azerbaijan & & 0.01 & 0.07 & Australia & & 0.01 & 0.07 & Austria & & 0.01 & 0.06 \\
\hline China & & 0.02 & 0.08 & China & & 0.02 & 0.07 & Barbados & & 0.01 & 0.07 & Barbados & & 0.01 & 0.07 & Australia & & 0.01 & 0.06 \\
\hline Germany & & 0.02 & 0.08 & France & & 0.02 & 0.07 & Belgium & & 0.01 & 0.07 & Bangladesh & & 0.01 & 0.07 & $\begin{array}{c}\text { Bosnia and } \\
\text { Herzegovina }\end{array}$ & & 0.01 & 0.06 \\
\hline Hong Kong & & 0.02 & 0.08 & UK & & 0.02 & 0.07 & $\begin{array}{r}\text { Burkina } \\
\text { Faso }\end{array}$ & & 0.01 & 0.07 & Belgium & & 0.01 & 0.07 & Barbados & & 0.01 & 0.06 \\
\hline Malaysia & & 0.02 & 0.08 & Indonesia & & 0.02 & 0.07 & Bulgaria & & 0.01 & 0.07 & Bulgaria & & 0.01 & 0.07 & Bangladesh & & 0.01 & 0.06 \\
\hline Singapore & & 0.02 & 0.08 & Lebanon & & 0.02 & 0.07 & Bermuda & & 0.01 & 0.07 & Bermuda & & 0.01 & 0.07 & Belgium & & 0.01 & 0.06 \\
\hline USA & & 0.02 & 0.08 & Netherlands & & 0.02 & 0.07 & Brunei & & 0.01 & 0.07 & Brunei & & 0.01 & 0.07 & $\begin{array}{r}\text { Burkina } \\
\text { Faso }\end{array}$ & & 0.01 & 0.06 \\
\hline UAE & & 0.01 & 0.07 & Singapore & & 0.02 & 0.07 & Bolivia & & 0.01 & 0.07 & Brazil & & 0.01 & 0.07 & Bulgaria & & 0.01 & 0.06 \\
\hline Brazil & & 0.01 & 0.07 & Thailand & & 0.02 & 0.07 & Brazil & & 0.01 & 0.07 & Belarus & & 0.01 & 0.07 & Bahrain & & 0.01 & 0.06 \\
\hline Canada & & 0.01 & 0.07 & $\begin{array}{r}\text { South } \\
\text { Africa }\end{array}$ & & 0.02 & 0.07 & Bahamas & & 0.01 & 0.07 & Canada & & 0.01 & 0.07 & Bermuda & & 0.01 & 0.06 \\
\hline Switzerland & & 0.01 & 0.07 & UAE & & 0.01 & 0.06 & Canada & & 0.01 & 0.07 & Congo & & 0.01 & 0.07 & Brunei & & 0.01 & 0.06 \\
\hline Chile & & 0.01 & 0.07 & Argentina & & 0.01 & 0.06 & $\begin{array}{r}\text { Dem. } \\
\text { R.Congo }\end{array}$ & & 0.01 & 0.07 & Switzerland & & 0.01 & 0.07 & Bolivia & & 0.01 & 0.06 \\
\hline Spain & & 0.01 & 0.07 & Austria & & 0.01 & 0.06 & Congo & & 0.01 & 0.07 & Ivory Coast & & 0.01 & 0.07 & Brazil & & 0.01 & 0.06 \\
\hline Finland & & 0.01 & 0.07 & Belgium & & 0.01 & 0.06 & Switzerland & & 0.01 & 0.07 & Chile & & 0.01 & 0.07 & Bahamas & & 0.01 & 0.06 \\
\hline Fiji & & 0.01 & 0.07 & Bahrain & & 0.01 & 0.06 & Ivory Coast & & 0.01 & 0.07 & Colombia & & 0.01 & 0.07 & Bhutan & & 0.01 & 0.06 \\
\hline France & & 0.01 & 0.07 & Bermuda & & 0.01 & 0.06 & Chile & & 0.01 & 0.07 & Cyprus & & 0.01 & 0.07 & Botswana & & 0.01 & 0.06 \\
\hline Indonesia & & 0.01 & 0.07 & Bolivia & & 0.01 & 0.06 & Cameroon & & 0.01 & 0.07 & Czechia & & 0.01 & 0.07 & Canada & & 0.01 & 0.06 \\
\hline Ireland & & 0.01 & 0.07 & Brazil & & 0.01 & 0.06 & Colombia & & 0.01 & 0.07 & Germany & & 0.01 & 0.07 & $\begin{array}{r}\text { Dem. } \\
\text { R.Congo }\end{array}$ & & 0.01 & 0.06 \\
\hline India & & 0.01 & 0.07 & Bahamas & & 0.01 & 0.06 & Cyprus & & 0.01 & 0.07 & Denmark & & 0.01 & 0.07 & Congo & & 0.01 & 0.06 \\
\hline Japan & & 0.01 & 0.07 & Canada & & 0.01 & 0.06 & Czechia & & 0.01 & 0.07 & Algeria & & 0.01 & 0.07 & China & & 0.01 & 0.06 \\
\hline
\end{tabular}

${ }^{2} \mathrm{BC}$ is Betweenness Centrality. DC is Degree Centrality. EG is Eigenvector Centrality. 
